\title{
Screening of Oat (Avena Sativa) Varieties in Saline- Sodic Soil
}

\author{
Muhammad Arshad Ullah'*, Imdad Ali Mahmood ${ }^{1}$, Muhammad Sarwar ${ }^{1}$ and Muhammad \\ Rasheed $^{2}$ \\ ${ }^{1}$ Land Resources Research Institute, National Agricultural Research Centre, Pakistan
}

${ }^{2}$ Agronomy Department, University of Arid Agriculture, Pakistan

*Corresponding author: Muhammad Arshad Ullah, Land Resources Research Institute, National Agricultural Research Centre, Islamabad, Pakistan

To Cite This Article: Muhammad Arshad Ullah. Screening of Oat (Avena Sativa) Varieties in Saline-Sodic Soil. Am J Biomed Sci \& Res. 2019 4(2). AJBSR.MS.ID.000773. DOI: 10.34297/AJBSR.2019.04.000773

Received: July 03, 2019 | Published: July 23, 2019

\begin{abstract}
Oat has much privileged sodium ion levels than wheat, soybean, cotton, and other seasonal crops. Oat cultivation is still well thought-out to stand for a supportive biological assess to recover saline lands due to its high capability to accrue salt ions in its straw, which is widely used as forage for livestock. Seeds of Oat (Avena sativa) were sown in a pot study to different combinations of salinity and sodicity $\left[\mathrm{S}_{0}=4.70 \mathrm{dSm}^{-1}+19.12\left(\mathrm{mmol} \mathrm{L}^{-1}\right)^{1 / 2}\right.$, $\mathrm{S}_{1}=9.02 \mathrm{dSm}^{-1}+30.65\left(\mathrm{mmol} \mathrm{L}^{-1}\right)^{1 / 2}$ and $\left.\mathrm{S}_{2}=11.35 \mathrm{dSm}^{-1}+34.69\left(\mathrm{mmol} \mathrm{L}^{-1}\right)^{1 / 2}\right]$. Seven oat varieties namely Bulbin, S-2000, Dilawar, PD2LV65, No.667, Bob and Cyprus were used for screening against salt tolerance. The leaset \% decrease in grain yield (35.24) was attained in S-2000 oat variety than other varieties. Therefore, this oat variety showed minimum loss due to toxic effects of salinity cum sodicity. Dilawar oat variety attained the highest grain yield $\left(1.38\right.$ tha $\left.^{-1}\right)$ under $\mathrm{S}_{2}\left[11.35 \mathrm{dSm}^{-1}+34.69\left(\mathrm{mmol} \mathrm{L}^{-1}\right)^{1 / 2}\right]$. Bulbin oat variety received the least position $\left(1.21\right.$ tha $\left.{ }^{-1}\right)$ in this salinity level. \% decrease at $\mathrm{S}_{2}$ over $\mathrm{S}_{0}$ was indicated salt tolerance of oat varieties. Bob oat variety attained the lowest $\%$ decrease at $\mathrm{S}_{2}$ over $\mathrm{S}_{0}(42.27)$. Therefore, this variety had the maximum salt tolerance other than six oat varieties under this experiment.
\end{abstract}

Keywords: Oat; Bulbin; S-2000; Dilawar; PD2LV65; No.667; Bob; Cyprus Saline- sodic; Grain yield

\section{Introduction}

Oat (Avena Linn.) is a vital cereal crop that is cultivated globally for fodder and grain. Oat is one of the oldest crops and is still extensively grown worldwide, including at high latitudes and in limiting climates. Oat is highly healthful for human and cattle utilization. Importance of oat in human nutrition is mounting due to traits e.g. cholesterol-lowering, antioxidant, and other healthrelated properties of oat and oat products and components [1,2]. The Avena genus includes some species referred to as naked oat, whose seeds are not as tightly husked as the others. Among these species, Avena chinensis is a leading crop and traditional food for local people in some marginal areas of north China affected by salinity and aridity, thus performing a significant responsibility in the local economy and natural environment [3]. Oat has much higher sodium ion levels comparing to wheat, soybean, cotton, and other seasonal crops [4-7]. Oat farming is still painstaking to signify a cooperative biological way to develop saline lands due to its high ability to gather salt ions in its straw, which is largely consumed as forage for livestock [8]. Nonetheless, abiotic stress tolerance is a quantitative attribute proscribed by numerous genes [9]. Oat is a type of cereal which is apt for special utilization with the world cool climate cereals and also our motherland. Moreover, being directly used in the human nutrition, oat is also consumed as an important raw material in biscuit industry. Furthermore, its straw and grain are also frequently used for animal nutrition. According to 2013 data, 235 thousand tons oat is produced in Turkey while it has a production volume of 2.4 million tons in the world [10].

Soil salinity is one of the limiting factors for plant production worldwide and the most important abiotic stress [11]. Up to now, approximately $7 \%$ of total land area (1,000 million ha) and $20 \%$ of the irrigated arable land in arid and semi-arid regions is salt affected and is increasing $[12,13]$. Salinization of agricultural soils causes reduction in crop growth, yields, and productivity due to ion imbalance and hyperosmotic stress. Sodium $\left(\mathrm{Na}^{+}\right)$and chloride $(\mathrm{Cl})$ are the two key ions responsible for significantly reduction in crop growth and yields because of osmotic and ion-specific damage [14].Therefore, traditional breeding as well as biotechnological 
approaches have been undertaken to increase the salt tolerance of plants by [15].

More than $10 \%$ of the cultivated are affected with drought and salinity which limit the planting and plant production. Approximately 50\% yield losses for many important plants are influenced by desertification and salinization in global level [16]. Salinization damaged approximately $15-20 \%$ of cultivated areas and $20-50 \%$ of irrigated farming areas of the world $[17,18]$. Salinity restricts development due to osmotic and ion stress and also indemnity at structural, physiological, biochemical and molecular levels [19].

As salinity stress concentration increases, germination reduced [20-24]. The oat varieties used in our study all had much weaker root development under salinity stress and the root development reduces at stress doses go up [24-30] specified that as the stress factor increased, there was considerable reduction in shoot development, which is one of the most important parameters at determining the stress tolerance of genotypes. With increasing stress, varieties had difficulty in germination and reduction of root / shoot development and fresh weight [31,32]. The utilization of starch stored in the endosperm of the seeds becomes limited at the salinity stress rises [33]. Therefore, this study was planned to evaluate the salt tolerance of oat varieties.

\section{Materials and Methods}

A pot study was conducted to evaluate the salt tolerance of oat varieties under different salinity cum sodicity levels $\left[\mathrm{S}_{0}=4.70 \mathrm{dSm}^{-1}+\right.$ $19.12\left(\mathrm{mmol} \mathrm{L}^{-1}\right)^{1 / 2}, \mathrm{~S}_{1}=9.02 \mathrm{dSm}^{-1}+30.65\left(\mathrm{mmol} \mathrm{L}^{-1}\right)^{1 / 2}$ and $\mathrm{S}_{2}=$ $\left.11.35 \mathrm{dSm}^{-1}+34.69\left(\mathrm{mmol} \mathrm{L}^{-1}\right)^{1 / 2}\right]$.Seeds of seven oat varieties namely Bulbin, S-2000, Dilawar, PD2LV65, No.667, Bob and Cyprus were used for screening against salt tolerance were sown in a pot study to different combinations of salinity and sodicity at green house of Land Resources Research Institute, National Agricultural
Research Centre, Islamabad, Pakistan during, 2018. $10 \mathrm{Kg}$ soil was used to fill each pot. 10 seeds of Oat (Avena sativa) were sown in each pot. Fertilizer was applied @60-50-40 NPK Kg ha-1. Completely randomized deign was applied with three repeats. Data on grain yield were collected. Collected data were statistically analysed and means were compared by LSD at $5 \%$ [34].

\section{Results and Discussions}

Sodium ion level is much elevated in oat than wheat, soybean, cotton, and other seasonal crops [4-7]. Oat cultivation is still measured to signify a supportive biological assess to develop saline lands owing to its high salt ion accumulation capacity in its straw and mostly consumed for livestock forage [8] Data indicated in table-1 showed significant differences in grain yield among seven oat varieties. At $\mathrm{S}_{0}\left[4.70 \mathrm{dSm}^{-1}+19.12\left(\mathrm{mmol} \mathrm{L}^{-1}\right)^{1 / 2}\right]$ Dilawar oat variety attained the highest grain yield $\left(2.44\right.$ tha $\left.^{-1}\right)$ which was statistically similar to No.667oat variety. All other oat varieties under $S_{0}$ $\left[4.70 \mathrm{dSm}^{-1}+19.12\left(\mathrm{mmol} \mathrm{L}^{-1}\right)^{1 / 2}\right]$ showed similar statistically results. Reduction in germination, root/ shoot development and grain yields with increasing salinity stress [31,32].

No.667oat variety got the top position in producing grain yield $\left(1.52\right.$ tha $\left.^{-1}\right)$ among other oat varieties at $S_{1}\left[9.02 \mathrm{dSm}^{-1}+30.65(\mathrm{mmol}\right.$ $\left.\mathrm{L}^{-1}\right)^{1 / 2}$. Cyprus oat variety gained the least grain yield $\left(1.35 \mathrm{tha}^{-1}\right)$ that was statistically at par with Bulbin oat variety (Table 1) also depicted very interesting data in $\%$ decrease at $\mathrm{S}_{1}$ over $\mathrm{S}_{0}$. The lease $\%$ decrease in grain yield (35.24) was attained in S-2000 oat variety than other varieties. Therefore, this oat variety showed minimum loss due to toxic effects of salinity cum sodicity. Salinization causes more than $50 \%$ yield losses for many important plants [16]. Sodium $(\mathrm{Na}+)$ and chloride ( $\mathrm{Cl}-)$ are the two key ions responsible for both osmotic and ion-specific damage, which significantly reduce crop growth and yields [14]. Increasing salinity and sodicity affected inverse on grain yield of these oat varieties as presented in (Table 1).

\begin{tabular}{|c|c|c|c|c|c|}
\hline Varieties & $S_{0}$ & $s_{1}$ & \%decrease at $S_{1}$ over $S_{0}$ & $\mathbf{S}_{2}$ & $\%$ decrease at $S_{2}$ over $S_{0}$ \\
\hline Bulbin & $2.25 \mathrm{~b}$ & $1.36 \mathrm{~d}$ & 39.55 & $1.21 \mathrm{~d}$ & 46.22 \\
\hline S-2000 & $2.27 \mathrm{~b}$ & $1.47 \mathrm{~b}$ & 35.24 & $1.24 \mathrm{~d}$ & 45.37 \\
\hline Dilawar & $2.44 \mathrm{a}$ & 1.46abc & 40.16 & $1.38 \mathrm{a}$ & 43.44 \\
\hline PD2LV65 & $2.36 \mathrm{ab}$ & $1.48 \mathrm{ab}$ & 37.28 & $1.31 \mathrm{bc}$ & 44.49 \\
\hline No.667 & $2.42 \mathrm{a}$ & $1.52 \mathrm{a}$ & 37.19 & $1.36 \mathrm{ab}$ & 43.8 \\
\hline Bob & $2.20 \mathrm{~b}$ & $1.40 \mathrm{~cd}$ & 36.36 & $1.27 \mathrm{~cd}$ & 42.27 \\
\hline Cyprus & $2.23 \mathrm{~b}$ & $1.35 \mathrm{~d}$ & 39.46 & $1.25 \mathrm{~cd}$ & 43.94 \\
\hline LSD & 0.13 & 0.07 & -------- & 0.07 & ----- \\
\hline
\end{tabular}

$\mathrm{S}_{0}=\left[4.70 \mathrm{dSm}^{-1}+19.12\left(\mathrm{mmol} \mathrm{L}^{-1}\right)^{1 / 2}\right] \mathrm{S}_{1}=\left[9.02 \mathrm{dSm}^{-1}+30.65\left(\mathrm{mmol} \mathrm{L}^{-1}\right)^{1 / 2}\right] \mathrm{S}_{2}=\left[11.35 \mathrm{dSm}^{-1}+34.69\left(\mathrm{mmol} \mathrm{L}^{-1}\right)^{1 / 2}\right]$

Dilawar oat variety attained the highest grain yield (1.38 tha $\left.{ }^{1}\right)$ under $S_{2}\left[11.35 \mathrm{dSm}^{-1}+34.69\left(\mathrm{mmol} \mathrm{L}^{-1}\right)^{1 / 2}\right]$. Bulbin oat variety received the lease position $\left(1.21\right.$ tha $\left.^{-1}\right)$ in this salinity level. \% decrease at $\mathrm{S}_{2}$ over $\mathrm{S}_{0}$ was indicated salt tolerance of oat varieties. Bob oat variety attained the lowest $\%$ decrease at $S_{2}$ over $S_{0}(42.27)$. Therefore, this variety had the maximum salt tolerance than other six oat varieties under this experiment. As salinity stress concentration increases, germination reduced [20-23,25]. The oat varieties used in our study all had much weaker root development under salinity stress and the root development reduces at stress doses go up [2430] investigated that as the salinity raised, the significant reduction in shoot development being the most important parameters to evaluate determining the salt tolerance in various genotypes. 


\section{Conclusion}

Bulbin oat variety received the lease position (1.21 tha $\left.\mathrm{a}^{-1}\right)$ under $\mathrm{S}_{2}\left[11.35 \mathrm{dSm}^{-1}+34.69\left(\mathrm{mmol} \mathrm{L}^{-1}\right)^{1 / 2}\right] . \%$ decrease at $\mathrm{S}_{2}\left[11.35 \mathrm{dSm}^{-1}\right.$ $\left.+34.69\left(\mathrm{mmol} \mathrm{L}^{-1}\right)^{1 / 2}\right]$ over $\mathrm{S}_{0}\left[4.70 \mathrm{dSm}^{-1}+19.12\left(\mathrm{mmol} \mathrm{L}^{-1}\right)^{1 / 2}\right]$ was indicated salt tolerance of oat varieties. Bob oat variety attained the lowest \% decrease at $\mathrm{S}_{2}$ over $\mathrm{S}_{0}$ (42.27). Therefore, this variety had the maximum salt tolerance than other six oat varieties under this experiment.

\section{References}

1. Anderson JW, Baird P, Davis RH, Ferreri S, Knudtson M, et al. (2009) Health benefits of dietary fiber. Nutr Rev 67(4):188-205.

2. Kristensen M, Buegel S (2011) A diet rich in oat bran improves blood lipids and hemostatic factors and reduces apparent energy digestibility in young healthy volunteers. Eur J Clin Nutr 65(9): 1053-1058.

3. Ren CZ, Hu YG (2013) China OATs. (1 $1^{\text {st }}$ edn), Beijing: China Agriculture Press.

4. Wang B, Song FB (2006) P hysiological responses and adaptive capacity of oats to saline-alkali stress. Ecology and Environment. Ecol. Environ 15(3): 625-629.

5. Yan XK, Chang KW, Xu HL (2005) Effects of paper mill sludge on potassium, sodium, calcium, and magnesium concentrations in different soybean cultivars. Pedosphere 15(1): 84-89.

6. Ashraf M, Ahmad S (2000) Influence of sodium chloride ion accumulation, yield components and fibre characteristics in salt-tolerant and saltsensitive lines of cotton. Field Crops Research 66(2): 115-127.

7. Munns R, James RA, LaÈuchli A (2006) Approaches to increasing the salt tolerance of wheat and other cereals. J Exp Bot 57(5): 1025-1043.

8. Han LP, Liu HT, Yu SH, Wang WH, Liu JT (2013) Potential application of oat for phytoremediation of salt ions in coastal saline-alkali soil. Ecological Engineering 61: 274-281.

9. Deinlein U, Stephan AB, Horie T, Luo W, Xu G, et al. (2014) Plant salttolerance mechanisms. Trends Plant Sci 19(6): 371-379.

10. Anonymous (2016) Food and Agriculture Organization (FAO).

11. Zhu JK (2001) Plant salt tolerance. Trends Plant Sci 6(2): 66-71.

12. MuÈhling $\mathrm{KH}$, LaÈuchli A (2003) Interaction of $\mathrm{NaCl}$ and $\mathrm{Cd}$ stress on compartmentation pattern of cations, antioxidant enzymes and proteins in leaves of two wheat genotypes differing in salt tolerance. Plant and Soil 253: 219-231.

13. Agarwal PK, Shukla PS, Gupta K, Jha B (2013) Bioengineering for Salinity Tolerance in Plants: State of the Art. Mol Biotechnol. 54(1): 102-123.

14. Munns R, Tester M (2008) Mechanisms of salinity tolerance. Annu Rev Plant Biol 59: 651-681.

15. Flowers TJ (2004) Improving crop salt tolerance. J Exp Bot 55(396): 307-319.

16. Bartels D, Sunkar R (2005) Drought and salt tolerance in plants. Critical reviews in plant sciences 24(1): 23-58.

17. Pitman MG, Läuchli A (2002) Global Impact of Salinity and Agricultural Ecosystems. Salinity: Environment-Plants-Molecules. Kluwer Academic Publishers. Dordrecht. The Netherlands 3-20.
18. Tuteja N (2007) Mechanisms of High Salinity Tolerance in Plants. Methods Enzymol 428: 419-438.

19. Çulha Ș, Çakırlar H (2011) Tuzluluğun Bitkiler Üzerine Etkileri ve Tuz Tolerans Mekanizmaları. Afyon Kocatepe Üniversitesi Fen Bilimleri Dergisi 11(2): 11-34

20. Pancholi SR, Bhargava SC, Singh AK (2001) Screening of wheat genotypes at different salinity levels for germination percentage. Annals of Agricultural Biological Research 6(1): 53-55.

21. Prazak R (2001) Salt tolerance of Triticum monococcum L., T. dicoccum (Schrank) Schubl. T. durum Desf. and T. aestivum L. seedlings. J Appl Genet 42(3): 289-292.

22. ȘenayA,Kaya MD, Atak M, Çiftçi CY(2005)Farklı Tuz Konsantrasyonlarının Bazı Ekmeklik Buğday Çeşitlerinin Çimlenme ve Fide Gelişimi Üzerine Etkileri. Tarla Bitkileri Merkez Araștırma Enstitüsü Dergisi 14(1-2): 5055.

23. Kara B, Akgün İ, Altındal D (2011) Tritikale Genotiplerinde Çimlenme ve Fide Gelișimi Üzerine Tuzluluğun ( $\mathrm{NaCl}$ ) Etkisi. Selcuk Tarim ve Gida Bilimleri Dergisi 25(1): 1-9.

24. Sadat NSA, McNeilly T (2000) Assessment of variability in salt tolerance based on seedling growth in Triticum durum Desf. Genetic Resources and Crop Evolution 47(3): 285-291.

25. Benlioğlu B, Özkan U (2015) Bazı Arpa Çeșitlerinin (Hordeum vulgare L.) Çimlenme Dönemlerinde Farklı Dozlardaki Tuz Stresine Tepkilerinin Belirlenmesi. Tarla Bitkileri Merkez Araştırma Enstitüsü Dergisi 24(2) 109-114.

26. Jamil M, Lee CC, Rehman SU, Lee DB, Ashraf M, et al. (2005) Salinity $(\mathrm{NaCl})$ tolerance of Brassica species at germination and early seedling growth. Electronic Journal of Environmental, Agricultural and Food Chemistry 4: 970-976.

27. Dumlupınar Z, Kara R, Dokuyucu T, Akkaya A (2007) Güneydoğu Anadolu Bölgesinde Yetiștirilen Bazı Makarnalık Buğday Genotiplerinin Çimlenme ve Fide Karakterlerine Elektrik Akımı ve Tuz Konsantrasyonlarının Etkileri. Kahramanmaraş Sütçü İmam Üniversitesi Fen Bilimleri Dergisi 10(2): 100-110.

28. Jafarzadeh A, Aliasgharzad N (2007) Salinity and salt composition effects on seed germination and root length of four sugar beet cultivars. Biologia 62(5): 562-564.

29. El Madidi SAID, El Baroudi I, Aameur F B (2004) Effects of salinity on germination and early growth of barley (Hordeum vulgare L.) cultivars. International Journal of Agriculture \& Biology 6(5): 767-770.

30. Widodo, Patterson JH, Newbigin E, Tester M, Bacic A, et al. (2009) Metabolic responses to salt stress of barley (Hordeum vulgare L.) cultivars, Sahara and Clipper which differ in salinity tolerance. Journal of Experimental Botany 60(14): 4089-4103.

31. Saboora A, Kiarostami K, Behroozbayati F, Hajihashemi S (2006) Salinity $(\mathrm{NaCl})$ tolerance of wheat genotypes at germination and early seedling growth. Pakistan Journal of Biological Science 9(11): 2009-2021.

32. Karakullukçu E, Adak MS (2008) Bazı nohut (Cicer arietinum L.) çeşitlerinin tuza toleranslarının belirlenmesi. Tarım Bilimleri Dergisi 14(4): 313-319.

33. Almansouri M, Kinet JM, Lutts S (2001) Effect of salt and osmotic stresses on germination in durum wheat (Triticum durum Desf.). Plant and Soil 23(2): 243-254.

34. Montgomery DC (2001) Design and Analysis of Experiments ( $5^{\text {th }}$ edn), John Willey and Sons, New York, USA. p. 64-65. 